\title{
Prevalence of Lumbosacral Radiculopathy among Dentists
}

\author{
SHIMAA A. ABD EL-BASET, M.Sc.*; EMAN S. FAYEZ, Ph.D.* and NEVEN ABD EL-LATIF, Ph.D.** \\ The Departments of Neurology \& Neurosurgery* and Basic Science**, Faculty of Physical Therapy, Cairo University
}

\begin{abstract}
Background: The dentists are at high risk of lower backache problems.

Aim of the Study: Was to detect point prevalence of work related the lumbosacral radiculopathy (low back pain and sciatica) among dentists who are currently working in ministry of health in Cairo, Egypt.
\end{abstract}

Material and Methods: Specific questionnaire based on Roland Morris questionnaire and Modified Roland Morris questionnaire (RMQ, RMQ-L) were given to dentists who are currently working in Ministry of Health in Cairo, Egypt. Five hundred volunteer dentists participated in this study. The results of this study showed that the point prevalence of Work Related Low Back Pain (WRLBP) was $60.8 \%$, point prevalence work related leg pain was $35.2 \%$. There was no statistical significant difference between female and male subjects in the median values of Visual Analogue Scale (VAS), Roland Morris questionnaire (RMQ) back pain. On the other hand, the median value of Modified Roland Morris questionnaire (RMQ-L) was significantly higher in female group than in male. The median value of VAS was significantly higher in full time than in part time. On the other hand, there was no statistical significant difference between full time and part time in the median values of Roland Morris questionnaire (RMQ) back pain and Modified Roland Morris questionnaire (RMQ-L). The median value of VAS was significantly higher in training group than in non-training group. On the other hand, there was no statistical significant difference between training and non-training in the median values of Roland Morris Questionnaire (RMQ) back pain and Modified Roland Morris questionnaire (RMQ-L). The median value of VAS was significantly higher in Pediatric Dentists (PEDO) than both General Practitioner dentists (GP) and other specialties dentists. There was a positive correlation between Roland Morris Questionnaire (RMQ) back pain and years of experience, VAS and RMQ leg. On the other hand, there was no statistical significant correlation between Roland Morris Questionnaire (RMQ) back pain and age and Body Mass Index (BMI). There was a positive correlation between Modified Roland Morris questionnaire RMQ leg and VAS.

Conclusion: Work-related low back pain is common among Egyptian DENTISTS at the POINT prevalence, Making Cairo's dentists at a high-risk group, which necessitate appropriate intervention to manage such squeal.

Correspondence to: Dr. Shimaa A. Abd El-Baset, The Department of Neurology \& Neurosurgery, Faculty of Physical Therapy, Cairo University
Key Words: Prevalence - Lumbosacral radiculopathy - Low back pain - Sciatica - Dentists - Egyptian.

\section{Introduction}

JOB-RELATED Musculoskeletal Disorders (MSDs) usually resulting from repeated workload exposures over a period of time, resulting from repeated workload exposures are commonly low back [1]. Dentists are at high risk for neck and back pain due to bad working postures, repetitive work, and prolonged standing that result in damage to muscles, joints, bones, ligaments, tendons, nerves, and blood vessels, which can then lead to pain, fatigue, and various MSDs. Low Back Pain (LBP) is the most frequent complaint, and almost all dentists worldwide have experienced this during their careers [2-4].

Musculoskeletal disorders are common in patients suspected of having lumbosacral radiculopathy [5] . Radiculopathy is a disorder involving compression, impingement, irritation or inflammation of a spinal nerve root, which may be due to a disc protrusion or any local degenerative disorder compromising the intervertebral foramen [6] Occupational hazards are common in various populations significantly Musculoskeletal Disorders (MSDs) [7].

Dental professionals are predisposed to a number of occupational hazards include musculoskeletal disorders exposure to infections; percutaneous exposure incidents, dental materials, radiation, and noise and other [8]

\section{Material and Methods}

Five hundred dentists (both sex) were participated in the study. They were selected randomly from the Outpatient Clinic of Dental Department of Hospitals of Ministry of Health in Cairo-Egypt, cross section study; single group related measure- 
ment design. The duration of this study was (6) months started from March 2017 to September 2017.

\section{Inclusive criteria:}

The age of the subjects will be ranged from 2535 years old; all subjects working in Ministry of Health in Cairo-Egypt; BMI $<35$.

\section{Exclusive criteria:}

Subjects with history of bone disease, renal, liver or endocrinal disorders; having lumbosacral radiculopathy before working as dentists, having trauma in back or accident and pregnant dentists were excluded.

Out of 510 dentists working in Ministry of Health in Cairo-Egypt: Ten was excluded due to history of trauma or diseases didn't submit making the final number of dentists included in the study is 500 .

Informed consent form was signed by each subject. This study was approved by Ethical Comity of Faculty of Physical Therapy, Cairo University (No:P.T.REC/012/001550).

\section{Instrumentation:}

Recording data sheet: Name, gender, age, address, years of experiences (years), type of chair, specialist. Work status, postgraduate training, direct question about having back pain and also about having leg pain, weight and height, visual analog scale: The Roland-Morris disability scale (RMS) for disability secondary to low back pain is a validated and popular instrument in clinical practice and Research and Modified Roland-Morris disability scale for leg pain (RMQ-L).

\section{Experimental procedures:}

- Through a personal visit of the first author to the hospitals in Cairo, the questionnaire was delivered personally to the dentists and through e-mails, and then researcher explained the aim of the study to the dentists, then the questionnaires were collected upon answering completion.

- Informed consent of scientific publication of the questionnaire provided data was included as a part of the questionnaire.

- If any of the dentists in the hospital didn't fill out the questionnaire, a follow-up visit one week after the first visit was commenced to make sure all dentists have the questionnaire and to collect newly filled out questionnaires.
Statistical analysis:

- Data was collected from the questionnaires and the result of assessment entered to SPSS program.

- Descriptive analysis (mean, standard deviation and $p$-value) were conducted.

- Comparisons between two groups used Mann Whitney test.

- Comparisons between three groups used Chi square value $=$ Kruskal Wallis test.

- Correlation analysis used Spearman's rho conducted to find the correlation between lumbosacral radiculopathy and body mass index, age, years of experiences.

The target population was dentists in Ministry of Health in Cairo and was characterized as follows and presented in tables.

\section{Results}

Table (1): Descriptive statistics of VAS, RMQ back pain and RMQ leg in the studied group.

\begin{tabular}{|c|c|c|}
\hline & Number & Percent \\
\hline \multicolumn{3}{|l|}{ Age (yrs.): } \\
\hline Minimum-maximum & $25.0-35.0$ & \\
\hline Mean \pm SD & $28.77 \pm 3.05$ & \\
\hline \multicolumn{3}{|l|}{ Gender: } \\
\hline Female & 290 & 58.0 \\
\hline Male & 210 & 42.0 \\
\hline \multicolumn{3}{|l|}{ Weight: } \\
\hline Minimum-maximum & $49.0-119.0$ & \\
\hline Mean \pm SD & $73.48 \pm 14.23$ & \\
\hline \multicolumn{3}{|l|}{ Height: } \\
\hline Minimum-maximum & $150.0-194.0$ & \\
\hline Mean \pm SD & $167.74 \pm 9.36$ & \\
\hline \multicolumn{3}{|l|}{ BMI: } \\
\hline Minimum-maximum & $17.30-34.82$ & \\
\hline Mean \pm SD & $25.98 \pm 3.61$ & \\
\hline \multicolumn{3}{|l|}{ Experience (yrs.): } \\
\hline Minimum-maximum & $1.0-15.0$ & \\
\hline Mean \pm SD & $6.35 \pm 3.44$ & \\
\hline \multicolumn{3}{|l|}{ Working time: } \\
\hline Full time & 374 & 74.8 \\
\hline Part time & 126 & 25.2 \\
\hline \multicolumn{3}{|l|}{ Training: } \\
\hline No & 310 & 62.0 \\
\hline Yes & 190 & 38.0 \\
\hline
\end{tabular}

The age of the studied group ranged from 2535 years with a mean $( \pm S D)=28.77 \pm 3.05$ years. As regards, gender distribution, $290(58.0 \%)$ females and $210(42.0 \%)$ males were enrolled in this study. Their weight ranged from $49.0-119.0 \mathrm{~kg}$ with a mean $( \pm \mathrm{SD})=73.48 \pm 14.23$. Their height ranged from $150.0-194.0(\mathrm{~cm})$ with a mean $( \pm S D)=$ 167.74 \pm 9.36 . Their BMI ranged from 17.30-34.82 $\left(\mathrm{kg} / \mathrm{m}^{2}\right)$ with a mean $( \pm \mathrm{SD})=25.98 \pm 3.61$ (Table $)$ 
The experience of these dentist ranged from years with a mean $( \pm \mathrm{SD})=$ years. As regards, working time, 374 (74.8\%) were full time and 126 $(25.2 \%)$ were part.

There was $310(62.0 \%)$ dentists without training and $190(38.0 \%)$ have training.

Table (2): The percentage of dentists having back pain during work were $60.8 \%$ (304 dentists).

\begin{tabular}{lcc}
\hline & Number & Percent \\
\hline No & 196 & 39.2 \\
Yes & 304 & 60.8 \\
\hline
\end{tabular}

Table (3): The percentage of dentists having leg pain (sciatica) during work were $35.2 \%$ (176 dentists).

\begin{tabular}{lcc}
\hline & Number & Percent \\
\hline No & 324 & 64.8 \\
Yes & 176 & 35.2 \\
\hline
\end{tabular}

Table (4): The mean values of VAS, RMQ back pain, RMQ leg were $5.23 \pm 2.16,8.13 \pm 4.78,5.65 \pm 5.03$ respectively.

\begin{tabular}{ll}
\hline & Characteristics \\
\hline VAS: & \\
Minimum-maximum & $0.0-10.0$ \\
Mean \pm SD & $5.23 \pm 2.16$ \\
RMQ back pain: & \\
Minimum-maximum & $0.0-23.0$ \\
Mean \pm SD & $8.13 \pm 4.78$ \\
RMQ leg: & \\
Minimum-maximum & $0.0-24.0$ \\
Mean \pm SD & $5.65 \pm 5.03$ \\
\hline
\end{tabular}

Table (5): Specialty of the studied group.

\begin{tabular}{lcc}
\hline & Number & Percent \\
\hline GP & 261 & 52.2 \\
Other specialists & 123 & 24.6 \\
PEDO & 116 & 23.2 \\
\hline
\end{tabular}

There were 261 GP presented by $52.2 \%, 116$ PEDO presented by $23.2 \%$ and 123 other specialists presented by $24.6 \%$.

Table (6): Comparison between median values of VAS, RMQ back pain and RMQ leg in gender subgroups.

\begin{tabular}{|c|c|c|c|c|}
\hline & $\begin{array}{l}\text { Female } \\
(\mathrm{n}=290)\end{array}$ & $\begin{array}{c}\text { Male } \\
(n=210)\end{array}$ & $\begin{array}{c}\mathrm{Z} \# \\
\text { value }\end{array}$ & $\begin{array}{c}p- \\
\text { value }\end{array}$ \\
\hline - VAS & $\begin{array}{l}5.0 \\
(0.0-10.0)\end{array}$ & $\begin{array}{l}5.0 \\
(0.0-10.0)\end{array}$ & -1.163 & $\begin{array}{l}0.245 \\
\text { (NS) }\end{array}$ \\
\hline $\begin{array}{l}\cdot \mathrm{RMQ} \\
\text { back pain }\end{array}$ & $\begin{array}{l}8.0 \\
(0.0-21.0)\end{array}$ & $\begin{array}{l}8.0 \\
(0.0-23.0)\end{array}$ & -1.156 & $\begin{array}{l}0.248 \\
\text { (NS) }\end{array}$ \\
\hline • RMQ leg & $\begin{array}{l}5.0 \\
(0.0-24.0)\end{array}$ & $\begin{array}{l}4.0 \\
(0.0-22.0)\end{array}$ & -3.329 & $\begin{array}{l}0.001 \\
(\mathrm{~S})\end{array}$ \\
\hline
\end{tabular}

There was no statistical significant difference between female and male groups in the median values of VAS $(Z=1.163 ; p=0.245)$ and RMQ back pain $(Z=1.156 ; p=0.248)$. On the other hand, the median value of RMQ leg was significantly higher in female group than in male group $(\mathrm{Z}=$ $3.329 ; p=0.001)$.

Table (7): Comparison between median values of VAS, RMQ back pain and RMQ leg in working time subgroups.

\begin{tabular}{lllll}
\hline & $\begin{array}{c}\text { Full time } \\
(\mathrm{n}=374)\end{array}$ & $\begin{array}{c}\text { Part time } \\
(\mathrm{n}=126)\end{array}$ & $\begin{array}{c}\mathrm{Z} \# \\
\text { value }\end{array}$ & $\begin{array}{c}p \text { - } \\
\text { value }\end{array}$ \\
\hline - VAS & 6.0 & 5.0 & -3.484 & 0.001 \\
& $(0.0-10.0)$ & $(0.0-10.0)$ & & $(\mathrm{S})$ \\
- RMQ & 8.0 & 7.0 & -0.891 & 0.373 \\
back pain & $(0.0-21.0)$ & $(0.0-23.0)$ & & $\begin{array}{l}\text { (NS) } \\
\text { - RMQ leg }\end{array}$ \\
& 5.0 & 4.0 & -0.053 & 0.958 \\
& $(0.0-22.0)$ & $(0.0-24.0)$ & & $(\mathrm{NS})$ \\
\hline
\end{tabular}

The median value of VAS was significantly higher in full time group than in part time group $(\mathrm{Z}=-3.484 ; p=0.001)$. On the other hand, there was no statistical significant difference between full time and part time groups in the median values of RMQ back pain $(Z=-0.891 ; p=0.373)$ and RMQ $\operatorname{leg}(\mathrm{Z}=0.053 ; p=0.958)$.

Table (8): Comparison between median values of VAS, RMQ back pain and RMQ leg in training subgroups.

\begin{tabular}{lllll}
\hline & $\begin{array}{c}\text { No } \\
(\mathrm{n}=310)\end{array}$ & $\begin{array}{c}\text { Yes } \\
(\mathrm{n}=190)\end{array}$ & $\begin{array}{c}\mathrm{Z} \# \\
\text { value }\end{array}$ & $\begin{array}{c}p \text { - } \\
\text { value }\end{array}$ \\
\hline - VAS & 5.0 & 6.0 & -2.045 & 0.041 \\
& $(0.0-10.0)$ & $(0.0-10.0)$ & & $(\mathrm{S})$ \\
- RMQ & 8.0 & 8.0 & -0.012 & 0.991 \\
back pain & $(0.0-23.0)$ & $(0.0-21.0)$ & & $(\mathrm{NS})$ \\
- RMQ leg & 5.0 & 4.5 & -0.552 & 0.581 \\
& $(0.0-22.0)$ & $(0.0-24.0)$ & & $(\mathrm{NS})$ \\
\hline
\end{tabular}

The median value of VAS was significantly higher in training group than in non-training group $(\mathrm{Z}=-2.045 ; p=0.041)$. On the other hand, there was no statistical significant difference between training and non-training groups in the median values of $\mathrm{RMQ}$ back pain $(\mathrm{Z}=-0.012 ; p=0.991)$ and $\mathrm{RMQ}$ $\operatorname{leg}(Z=0.552 ; p=0.581)$.

There was a statistical significant difference between the three groups (Chi square test $=7.566$; $p=0.023$ ). Where the median value of VAS was significantly higher in PEDO group than both GP $(p=0.023)$ and other specialists $(p=0.010)$ groups. On t the other hand, there was no statistical significant difference between GP and other specialists groups $(p=0.426)$. 
Table (9): Comparison between median values of VAS in specialty subgroups.

\begin{tabular}{llllll}
\hline & $\begin{array}{c}\text { GP } \\
(\mathrm{n}=261)\end{array}$ & $\begin{array}{c}\text { Other } \\
\text { specialists } \\
(\mathrm{n}=123)\end{array}$ & $\begin{array}{c}\text { PEDO } \\
(\mathrm{n}=116)\end{array}$ & $\begin{array}{c}\text { Chi- } \\
\text { Square } \\
\text { value }\end{array}$ & $\begin{array}{c}p \text { - } \\
\text { value }\end{array}$ \\
\hline • VAS & 5.0 & 5.0 & 6.0 & 7.566 & 0.023 \\
& $(0.0-10.0)$ & $(0.0-9.0)$ & $(0.0-9.0)$ & & $(\mathrm{S})$ \\
• $p$-value vs & - & 0.426 & 0.023 & & \\
$\begin{array}{l}\text { GP } \\
\text { • } p \text { value vs } \\
\begin{array}{l}\text { other } \\
\text { specialists }\end{array}\end{array}$ & - & $(\mathrm{NS})$ & $(\mathrm{S})$ & & \\
\hline
\end{tabular}

Table (10): Comparison between median values of RMQ back pain and RMQ leg in specialty subgroups.

\begin{tabular}{rlllll}
\hline & \multicolumn{1}{c}{ GP } \\
$(\mathrm{n}=261)$ & $\begin{array}{c}\text { Other } \\
\text { specialists } \\
(\mathrm{n}=123)\end{array}$ & $\begin{array}{c}\text { PEDO } \\
(\mathrm{n}=116)\end{array}$ & $\begin{array}{c}\text { Chi- } \\
\text { Square } \\
\text { value }\end{array}$ & $\begin{array}{c}p \text { - } \\
\text { value }\end{array}$ \\
\hline - RMQ & 8.0 & 8.0 & 8.0 & 0.510 & 0.775 \\
back pain $(0.0-23.0)$ & $(0.0-21.0)$ & $(0.0-21.0)$ & & $(\mathrm{NS})$ \\
- RMQ leg 5.0 & 5.0 & 0.5 & 0.877 & 0.645 \\
$(0.0-24.0)$ & $(0.0-24.0)$ & $(0.0-19.0)$ & & $(\mathrm{NS})$ \\
\hline
\end{tabular}

There was no statistical significant difference between the three groups (Chi square test $=0.510$; $p=0.775$ ).

The median value of RMQ leg in GP, other specialists and PEDO groups were [5.0 (0.0-24.0)], [5.0 (0.0-24.0)] and [5.0 (0.0-19.0)], respectively. There was no statistical significant difference between the three groups (Chi square test $=0.877$; $p=0.645$ ).

Table (11): Correlation between RMQ back pain and RMQ leg and different parameters in the studied group.

\begin{tabular}{lcccc}
\hline & \multicolumn{2}{c}{ RMQ back pain } & \multicolumn{2}{c}{ RMQ leg } \\
\cline { 2 - 5 } & $r$ & $p$-value & $r$ & $p$-value \\
\hline Age & 0.077 & 0.085 & 0.037 & 0.414 \\
Experience & 0.102 & $0.022^{*}$ & 0.024 & 0.589 \\
BMI & 0.063 & 0.158 & 0.067 & 0.132 \\
VAS & 0.466 & $0.001 *$ & 0.344 & $0.001^{*}$ \\
RMQ back pain & & & 0.484 & $0.001^{*}$ \\
RMQ-L & 0.484 & $0.001 *$ & - & - \\
\hline
\end{tabular}

There was a positive correlation between RMQ back pain and experience $(r=0.102 ; p=0.022)$, VAS $(r=0.466 ; p=0.001)$ and RMQ leg $(r=0.484 ; p=$ $0.001)$. On the other hand, there was no statistical significant correlation between RMQ back pain and age ( $r=0.077 ; p=0.085)$ and BMI $(r=0.063 ; p=$ $0.158)$, there was a positive correlation between RMQ leg and VAS ( $r=0.344 ; p=0.001$ ). On the other hand, there was no statistical significant correlation between RMQ leg and age $(r=0.037$; $p=0.414)$, experience $(r=0.024 ; p=0.589)$ and BMI $(r=0.067 ; p=0.132)$.

\section{Discussion}

The present study was conducted to investigate the prevalence of lumbosacral radiculopathy among dentists. Five hundred dentists were participated in this study. The dentists were assigned into one group.

In the present study the dentist's age were maximally limited to 35 years in order to minimize the effect of age on physical functions of the participated dentists.

This study agrees with the study of Côté et al., (2015) who found that incidence of LDH with radiculopathy is most common among persons 30 50 years of age [9].

The current study found that median value of VAS was significantly higher in full time group than in part time group $(\mathrm{Z}=-3.484 ; p=0.001)$ which came in agreement with Garbin et at., who found that there has been high prevalence of musculoskeletal pain related to inadequate postures adopted during clinical assistance and to long working hours without pause. There has been job-related pain in at least $65.67 \%$ of dentists. The number of individuals adopting incorrect and inadequate positions during assistance was high, such as: Head rotation $(73.13 \%)$; spine rotation $(47.76 \%)$ and legs angle less than $90^{\circ}(91.04 \%)$. Medical leaves related to occupational injuries were found in a greater proportion among public service professionals $(64 \%)$ [10].

The current study come in agreement with the work of Hayes et al., who found that in analyzing the presence of pain or occupational injury, $65.67 \%$ of dentists have reported having some type of injury. In activities where movements are cyclic, short and repetitive, added to static muscle contraction caused by poor posture, more than ergonomic solutions are needed. Musculoskeletal pain complaint by dentists has been described by several authors who state that pain reports are very common among dentists due to the time they spend sitting down or working in a same posture, which most of the time is not ergonomic [11-14].

Barbosa et al., have stressed that $68.9 \%$ of inquired professionals had pain complaints at the end of the working day [15]

On the other hand this study come in agreement with the work of Hayes et al., who found that the 
presence of pain/injury related to dentists occupation was high in study $(65.67 \%)$ and there has been higher prevalence of musculoskeletal pain among females $(67.86 \%)$, result also found in most literature studies [16-19].

Also, the work of Wazzan et al., disagrees with findings of this study as he found that $-58.24 \%$ males and $41.75 \%$ females suffered with neck and lowered back pain [20].

The current study found that there was no statistical significant correlation between RMQ leg and age, experience and BMI which agrees with the work of Leino-Arjas et al., Who found evidence no association between inconvenient work postures and $\mathrm{LDH}$ with radiculopathy [21]. In addition, no association was reported between the incidence of LDH with radiculopathy and sedentary/sitting work [21-23] or bent occupational postures; working with hands above shoulders [22]; and prolonged standing at work [23]

The current study found that there was $60 \%$ of dentist complained of low back pain similar work of Subhash Chandra1 et al., (2015) found that $38.01 \%$ of dentists complained of the lumbar pain [24].

Also the work of Shaikhet et al., found that the majority of the patients $(73 \%)$ surveyed were found to be suffering from MSDS. Also reported a high incidence $(80 \%)$ of MSDS in their study in 30 dentists [25].

Among the MSDS, the incidence of low back pain $(73.3 \%)$ was highest. Various other studies also suggest high incidence of MSDS among dentists [26,27].

\section{Conclusion:}

So, it can be concluded that the prevalence of lumbosacral radiculopathy among dentists:

- Point prevalence of low back pain among dentists is $60.8 \%$ and point prevalence of low back pain among dentists is $35.2 \%$.

- According to VAS and RMQ back pain, it does not differ between male and female, but according to RMQ leg, it is higher in female group than in male group.

- According to working time, VAS is higher in full time group than in part time group, but RMQ back pain and RMQ leg do not differ between full time and part time.

- According to training, VAS is higher in training group than in non-training group, but RMQ back pain and RMQ leg do not differ between training and non-training.

- According to specialty:

- VAS is higher in PEDO group than both GP and other specialists, but VAS does not differ between GP and other specialists RMQ back pain and RMQ leg do not between GP, other specialists and PEDO.

- There are positive correlation between:

- RMQ back pain and experience, VAS and RMQ leg.

- RMQ leg and VAS.

But there are no correlations between:

- RMQ back pain and age, and BMI.

- RMQ leg and age, experience, and BMI.

- From the previous study we conclude that VAS was the best to assess pain among dentists. Pain and disability increase with increase years of experiences, full time working and post graduated training. PEDO dentists were at higher risk than others.

\section{References}

1- BERNACKI E.J., GUIDERA J.A., SCHAEFER J.A., et al.: An ergonomics program designed to reduce the incidence of upper extremity work related musculoskeletal disorders. J. Occup. Environ. Med., 41: 1032-41, 1999.

2- ABDULJABBAR T.: Musculoskeletal disorders among dentists in Saudi Arabia. Pak. Oral. Dent. J., 28: 135-44, 2005.

3- UDOYE C.I. and AGUWA E.N.: Musculoskeletal symptoms: A survey amongst a selected Nigerian dentist. Int. J. Dent. Sci., 5: 1-5, 2007.

4- PITTS F.M.: Musculoskeletal disorders in dentistry. Louisiana State University, 2005.

5- CANNON D.E., DILLINGHAM T.R., MIAO H., ANDARY M.T. and PEZZIN L.E.: Musculoskeletal disorders in referrals for suspected lumbosacral radiculopathy, Am. J. Phys. Med. Rehabil., 86 (12): 957-61, 2007.

6- MAITLAND G.D., HENGEVELD E., BANKS K. and ENGLISH K.: Maitland's Vertebral Manipulation, 7 th edn. Elsevier, Edinburgh, pp. 19-376, 2005.

7- SAXENA P., GUPTA S.K., JAIN S. and JAIN D.: WorkRelated Musculoskeletal Pain Among Dentists in Madhya Pradesh, India: Prevalence, Associated Risk Factors, and Preventive Measures. Asia Pac. J. Public Health, 26: 304 9, 2014

8- AYATOLLAHI J., AYATOLLAHI F., ARDEKANI A.M., BAHROLOLOOMI R., AYATOLLAHI J., AYATOLLAHI A. and OWLIA M.: Occupational hazards to dental staff Dent. Res. J. (Isfahan). Jan.-Mar., 9 (1): 2-7, 2012.

9- CÔTÉ P., BOYLE E., CHOI S., RAMPERSAUD Y.R., HINCAPIÉ C.A. and CASSIDY J.D.: Chiropractic care 
and the risk for cauda equina syndrome: A populationbased case-crossover study. In Progress, 2015.

10-ARTÊNIO JOSÉ ÍSPER GARBIN, CLÉA ADAS SALIBA GARBIN, RENATO MOREIRA ARCIERI, TÂNIA ADAS SALIBA ROVIDA and ANA CAROLINA Da GRAÇA FAGUNDES FREIRE: Musculoskeletal pain and ergonomic aspects of dentistry, Rev. Dor. São Paulo, Apr.-Jun., 16 (2): 90-5, 2015.

11- REGIS FILHO G.I., MICHELS G. and SELL I.: Lesões por esforços repetitivos/distúrbios osteomusculares relacionados ao trabalho em cirurgiões-dentistas. Rev. Bras. Epidemiol., 9 (3): 346-59. [Links], 2006.

12- GARBIN A.J., GARBIN C.A. and DINIZ D.G.: Normas e diretrizes ergonômicas em odontologia: $\mathrm{O}$ caminho para a adoção de uma postura de trabalho saudável. Rev. Odontol. Univ. Cid. São Paulo, 21 (2): 155-61. [Links], 2009.

13- HAYES M.J., SMITH D.R. and TAYLOR J.A.: Musculoskeletal disorders and symptom severity among Australian dental hygienists. B.M.C. Res. Notes, 6: 250. [Links], 2013.

14- ALEXANDRE P.C., Da SILVA I.C., De SOUZA L.M., De MAGALHÃES CÂMARA V., PALÁCIOS M. and MEYER A.: Musculoskeletal disorders among Brazilian dentists. Arch. Environ. Occup. Health, 66 (4): 231-5, [Links], 2011.

15-BARBOSA E.C., SOUZA F.M., CAVALCANTI A.L. and LUCAS R.S.: Prevalência de distúrbios osteomusculares relacionados ao trabalho de cirurgiões-dentistas de Campina Grande-PB. Pesq. Bras. Odontoped. Clin. Integr., 4 (1): 19-24, 2004.

16- REGIS FILHO G.I., MICHELS G. and SELL I.: Lesões por esforços repetitivos/distúrbios osteomusculares relacionados ao trabalho em cirurgiões-dentistas. Rev. Bras. Epidemiol., 9 (3): 346-59, 2006.

17- HAYES M.J., SMITH D.R. and TAYLOR J.A.: Musculoskeletal disorders and symptom severity among Australian dental hygienists. B.M.C. Res. Notes, 6: 250, 2013.
18-MOIMAZ S.A., SALIBA N.A. and BLANCO M.R.: [The women workforce in dentistry in Araçatuba-SP]. J. Appl. Oral. Sci., 11 (4): 301-5. Portuguese, 2003.

19- YI J., HU X., YAN B., ZHENG W., LI Y. and ZHAO Z.: High and specialty-related musculoskeletal disorders afflict dental professionals even since early training years. J. Appl. Oral. Sci., 21 (4): 376-82, 2013.

20- AL WAZZAN K.A., ALMAS K., AL SHETHRI S.E. and AL-QAHTANI M.Q.: Back \& neck problems among dentists and dental auxiliaries. J. Contemp. Dent. Pract., 2: 17-30, 2001.

21- LEINO-ARJAS P., KAILA-KANGAS L., KAUPPINEN T., NOTKOLA V., KESKIMÄKI I. and MUTANEN P.: Occupational exposures and inpatient hospital care for lumbar intervertebral disc disorders among Finns. Am. J. Ind. Med., 46: 513-20, 2004.

22- MIRANDA H., VIIKARI-JUNTURA E., MARTIKAINEN R., TAKALA E.P. and RIIHIMAKI H.: Individualfactors, occupational loading, and physical exercise as predictors of sciatic pain. Spine, 27: 1102-9, 2002.

23- 46. LECLERC A., TUBACH F., LANDRE M.F. and OZGULER A.: Personal and occupational predictors of sciatica in the GAZEL cohort. Occup. Med., 53: 384-91, 2003.

24- CHANDRA, et al.: Prevalence of Neck and Lower Back Pain among Dentists from Three Dental Colleges in Patna City, International Journal of Scientific Study, November, Vol 3, Issue 8, 2015.

25- SHAIK A.R., RAO S.B., HUSAIN A. and D'SA J.: Workrelated musculoskeletal disorders among dental surgeons: A pilot study. Contemp. Clin. Dent., 2: 308-12, 2011.

26- LEGGAT P.A. and SMITH D.R.: Musculoskeletal disorders self-reported by dentists in Queensland, Australia. Aust. Dent. J., 51: 324-7, 2006.

27- PARGALI N. and JOWKAR N.: Prevalence of musculoskeletal pain among dentists in Shiraz, Southern Iran. Int. J. Occup. Environ. Med., 1: 69-74, 2010. 


\section{إنتشار إعتلال جذور الفقرات القطنية العجزية بين آطباء الآسنان}

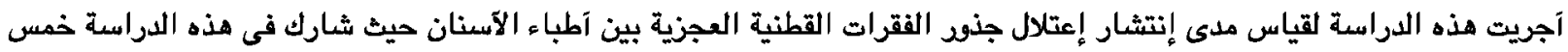

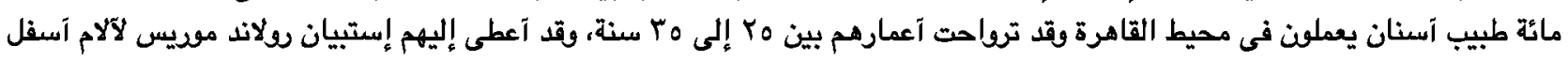
الظهر بالإضافة إلى النسخة المعدلة من إستبيان رولاد موديس لعرق النسا. وقد تم التقييم عبارة عن مقابلة شخصية واحدة يتم فيها ملئ الإستييان آو إرسالة عن طريق البريد الإليكترونى لجميع الآطباء.

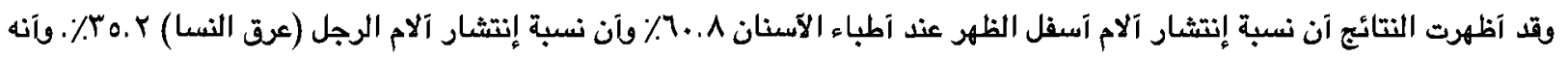

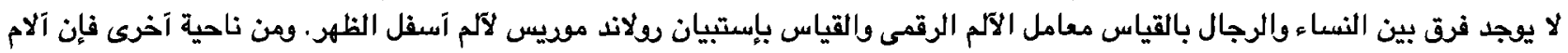

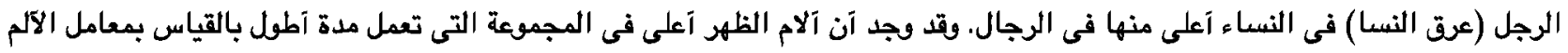

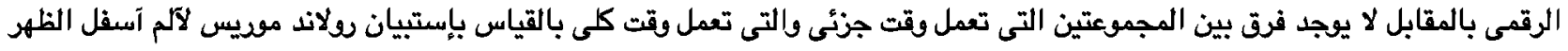

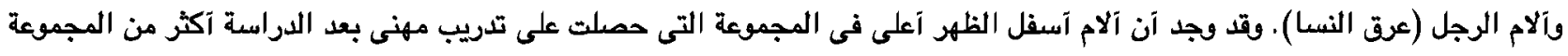

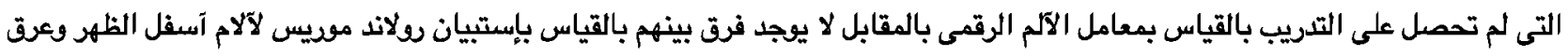

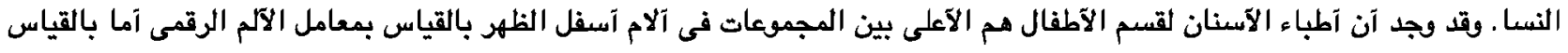

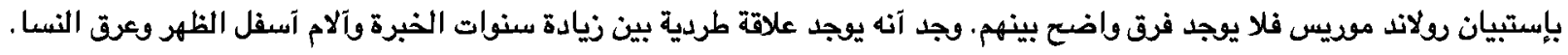

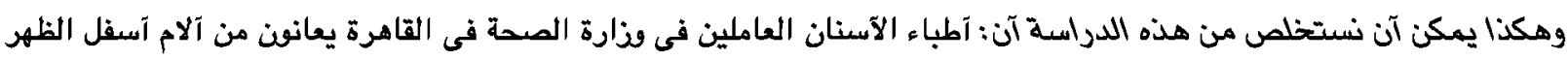

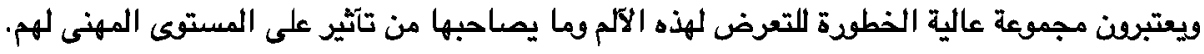

